\title{
Fetal and Postnatal Development of T-lymphocyte Subpopulations
}

\author{
F. KOVÁŘ Ư ${ }^{1}$, H. KOVÁŘ ${ }^{2}$, A. FIŠEROVÁ ${ }^{3}$, E. MATALOVÁ ${ }^{4}$, P. ZELNÍČKOVÁ ${ }^{1}$,
} L. LANDA ${ }^{5}$, M. PALÍKOVÁ

${ }^{1}$ University of Veterinary and Pharmaceutical Sciences, Brno, ${ }^{2}$ Charles University, $1{ }^{\text {st }}$ Faculty of Medicine, Prague, ${ }^{3}$ Institute of Microbiology, Academy of Sciences ČR, Prague, ${ }^{4}$ Institute of Animal Physiology and Genetics, Academy of Sciences ČR, Brno, ${ }^{5}$ Masaryk University, Faculty of Medicine, Department of Pharmacology, Brno, Czech Republic

Received August 19, 2002

Accepted November 18, 2002

\section{Abstract}

Kovářů F., H Kovářů, A. Fišerová, E. Matalová, P. Zelníčková, L. Landa, M. Palíková: Fetal and Postnatal Development of T-lymphocyte Subpopulations. Acta Vet. Brno 2002, 71: 495-502.

Changes in individual subpopulations of lymphocytes (mainly $\mathrm{CD} 2^{+}, \mathrm{CD}^{+}$and $\mathrm{CD} 8^{+}$) in primary and secondary lymphatic organs and circulating blood were observed in pig fetuses between days 51 and 112 of gestation, and in circulating blood in postnatal piglets. The technique of flow cytofluorimetry was used and binding of specific monoclonal antibodies was visualised using polyclonal antibodies against mouse or rat Ig marked with fluorochroms (PE and FITC). As soon as on day 51 of gestation, $\mathrm{CD}^{+}$and $\mathrm{CD}^{+} \mathrm{T}$ lymphocytes were demonstrated in porcine thymus. Their relative and actual numbers continued to increase markedly. When this increase was expressed in terms of age with subsequent intrapolation, the changes in $\mathrm{CD} 4^{+} / \mathrm{CD} 8^{+}$phenotype expression could be expected around day 40, i.e. in the period, when thymus cortex and medulla are not yet morphologically differentiated.

In the spleen only CD2 $2^{+}$cells were found on day 51 of gestation. Expression of lymphocytes with $\mathrm{CD}^{+}$and $\mathrm{CD}^{+}$receptors was shown on day 60 . Their relative and actual numbers increased with age. This increase when expressed per whole organ made a difference of three orders of magnitude. In lymph nodes, only changes from day 90 were followed. In this secondary lymphatic organ, the percentage of $\mathrm{T}$ lymphocytes with $\mathrm{CD} 4^{+}$and $\mathrm{CD} 8^{+}$markers was higher than that in the spleen. The $\mathrm{CD} 4^{+} / \mathrm{CD}^{+}$ratio in spleen and thymus gradually decreased with advancing age to 1 with a slightly dominant CD4 ${ }^{+}$ lymphocyte subpopulation. On the other hand, in lymph nodes of pig fetuses $\mathrm{CD}^{+}$lymphocytes prevailed (index 0.85 ). In the postnatal period, a marked increase of cytotoxic CD8 $8^{+}$lymphocytes occurred in peripheral blood of 28 -day-old piglets. Thus the $\mathrm{CD} 4^{+} / \mathrm{CD}^{+}$index decreased from 1 to 0.2 . This characteristic of lymphocyte subpopulations in circulating blood is also typical of adult individuals. The numbers of B lymphocytes with IgM receptors in circulating blood increased gradually from day 90 of prenatal development until day $28^{\mathrm{h}}$ of postnatal life both in relative and actual terms.

Prenatal ontogenesis, pig fetuses, lymphatic organs, quantitative cytology

Ontogenetic development of the individual lymphocyte subpopulations in lymphatic and haemopoietic organs has been in focus of interest of many research laboratories. As suitable experimental models for these studies animal species are used in which placentation preventing the transport of immunoglobulins between mother and fetus, i.e. those equipped with epitheliochorial or syndesmochorial placenta (Šterzl and Silverstein 1967). Therefore we used the porcine experimental model with an epitheliochorial type of placenta that fulfils the above-mentioned criteria (Plate III and IV, Fig. 1 and 2). Moreover, this model offers some other advantages such as appropriate litter size for the statistical analysis, a sufficiently long period of gestation (114 days) so that the individual developmental periods do not overlap, relatively good accessibility of this model and previously elaborated anaesthetic and surgical techniques in pregnant animals (Kovářů et al. 1971; Kovářủ and Stožický 1986; Reháková et al. 1996). 
Various aspects of the development of lymphatic and haemopoietic organs in this animal species such as quantitative morphology, quantitative cytology, cell biochemistry and molecular biology have been described in detail (Kovář ů et al. 1979; Kovářů et al. 1987; Kovář et al. 1988ab; Kovářů et al. 1994; Kovářů et al. 1995).

The first T lymphocytes have been documented in the epithelial base of thymus as soon as on day 28 (FD) of fetal development using polyclonal sheep anti-pig T cell antiserum with CD2 specificity (Trebichavský et al. 1985). The first B lymphocytes with IgM receptor were described in the liver on FD 44 (Prokešová et al. $1979 \mathrm{ab}$ ). Thus it is possible to speak about $\mathrm{T}-\mathrm{B}$ dichotomy during the second month of prenatal development (Kovářu et al. 1978) and it has been demonstrated that each lymphocyte is bearing only $\mathrm{T}$ or B phenotype (Jarošková and Kovář ů 1978). This was done using two types of labelling (production of spontaneous E-rosette forming cells as T markers and demonstration of IgM receptor as a $\mathrm{B}$ cell marker by microautoradiography.

Therefore the aim of this study is to further characterize the individual subpopulations of mainly T lymphocytes, i.e. to perform a qualitative and quantitative analysis of helper (CD4) and cytotoxic (CD8) T lymphocyte subpopulation as well as CD2 cells during the prenatal and early postnatal pig life in primary and secondary lymphatic organs, and in circulating blood. Cytological changes were expressed as percentage of total amount, related to one gram of wet weight or to whole organ mass, suggesting the capacity of immune system in respect to different effector structure elements, because there are no quantitative data in published papers dealing with these problems.

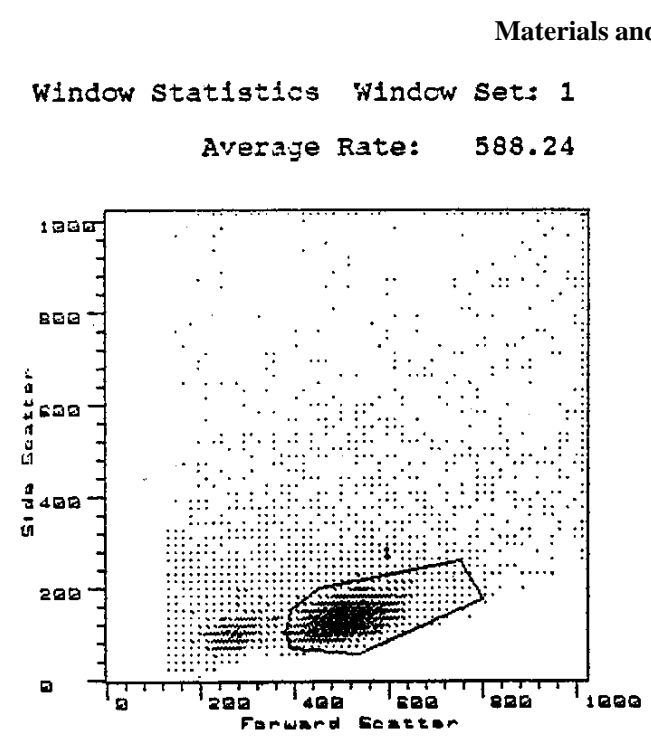

Fig. 3. Typical working "window" for pig lymphocytes in measured cell suspensions characterized relative values of side and forward scatter
Fetuses of 5 pregnant sows (Czech LargeWhite) from FD 55 to FD 112 (a total of 34 fetuses) were used. Further, blood samples from 8 piglets of the same breed were collected on postnatal day (PD) 28 . For obtaining fetuses during the prenatal development the technique for fetal surgery and halothan- $\mathrm{O}_{2}$ anaesthesia of the mother with maintenance of basal physiological indices in fetuses and mother (Kovář̉ et al. 1971; Kovářủ and Stožický 1986; Řeháková et al. 1996). For isolation of the cells from the primary and secondary lymphatic organs and their characterization the techniques of classical and quantitative cytology were used (Kovář́ et al. 1987; Kovář̉ et al. 1992) with the following separation of lymphocyte subpopulations on discontinous gradient of Histopaque 1077 (Sigma). For phenotyping of the individual lymphocyte populations murine monoclonal antibodies (MoAb) against pig T lymphocytes PT4 (anti-CD4) and SL2 (anti-CD8) and rat MoAb against pig CD2 receptor (Mac80) were used. CD4 and CD8 MoAbs were provided by Dr. Rothkotter from the University of Medical Sciences, Hannover. MoAbs were developed at the University of Tübingen (Germany) and CD2 MoAb was kindly provided by Dr. Binns, Babraham Institute of Animal Physiology, Cambridge (United Kingdom). Mouse MoAbs against IgM receptor (Lig4) used only for lymphocytes of circulating blood originated from Ing. Petr Dvořák's laboratory, Academy of Sciences of the Czech Republic. As $2^{\text {nd }}$ antibodies we used phycoerythrin-Fab fragment conjugate of goat anti-mouse polyclonal Ig (Becton Dickinson) as well as conjugate of FITC-rabbit anti-mouse (or rat) polyclonal Ig (DaKo immunoglobulins). Cells were analysed by flow cytofluorimetry (FACS) analysis (Becton Dickinson). Typical histograms of the individual subpopulation of T lymphocytes, including working "window" for pig lymphocytes characterized relative levels side and forward scatter and set up of the background using controls are depicted in Figs 3, 4 and 5. 

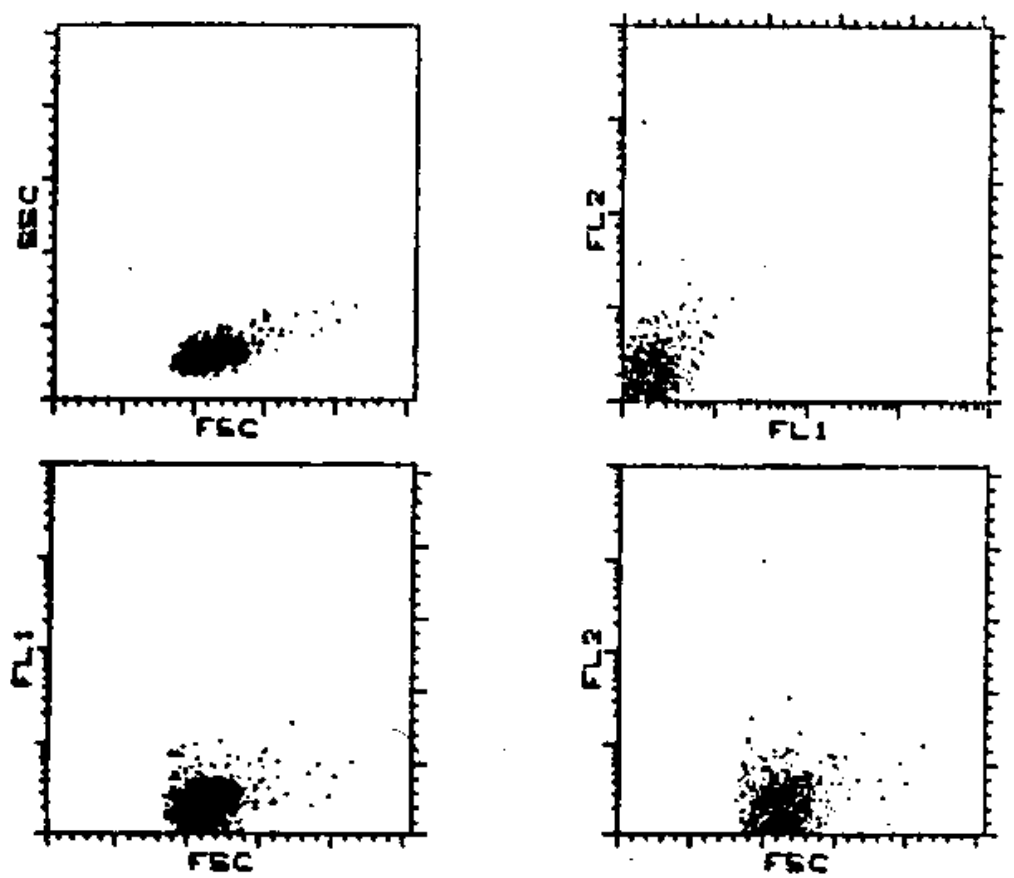

CONTROL - THYMUS ONLY

\section{PE CONJUGATE}

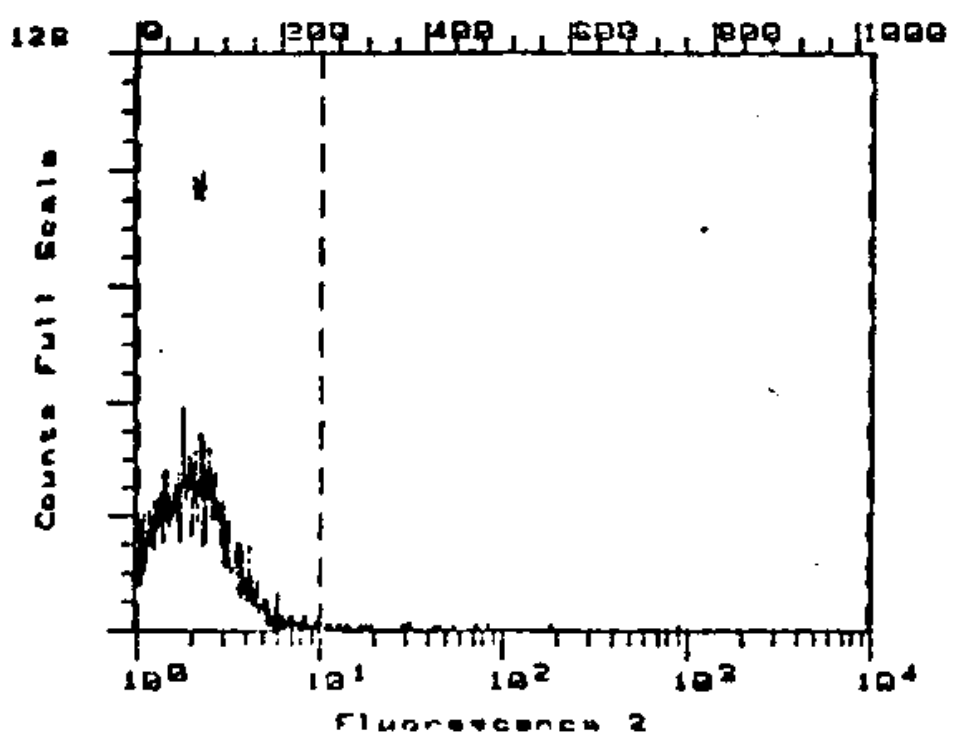

Fig. 4. Histogram of control activity of thymus cells with PE conjugate 

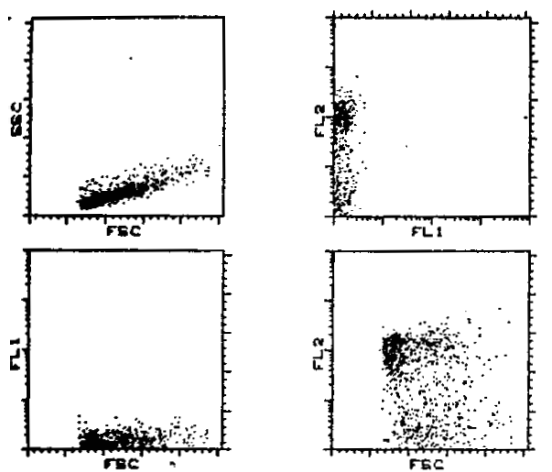

THYMUS CD 4 - DAY 90

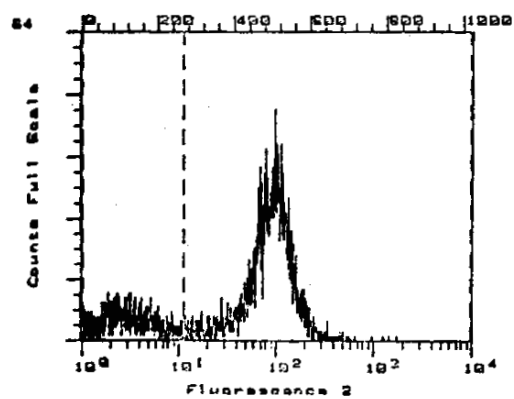

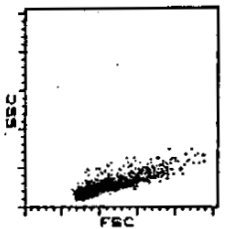
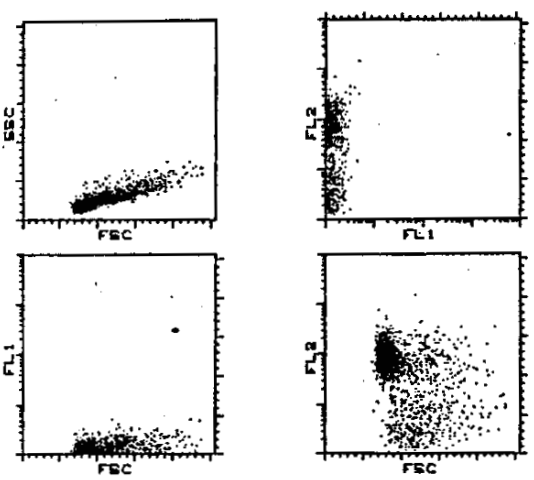

THYMUS CD 8 - DAY 90

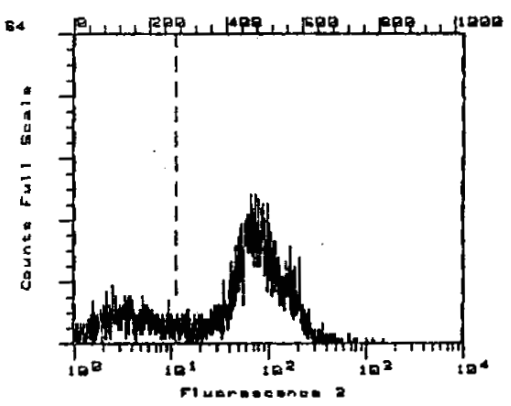

Fig. 5. Histogram of $\mathrm{CD}^{+}$and $\mathrm{CD} 8^{+}$thymic lymphocytes

\section{Results and Discussion}

In the thymus, a primary lymphatic organ, $\mathrm{CD} 2^{+}$and also $\mathrm{CD}^{+}{ }^{+}$and $\mathrm{CD} 8^{+} \mathrm{T}$ lymphocytes were confirmed as soon as on FD 51. Their percentage proportion rose significantly from FD 51 to FD $60\left(\mathrm{CD}^{+}\right.$and $\left.\mathrm{CD}^{+}\right)$. For $\mathrm{CD}^{+}$T lymphocytes this increase was evident until FD 90 (Table 1). When expressed per 1 gram of wet weight and per whole organ mass for all three categories of thymus lymphocytes, this increase is evident until FD 90 and FD 112,

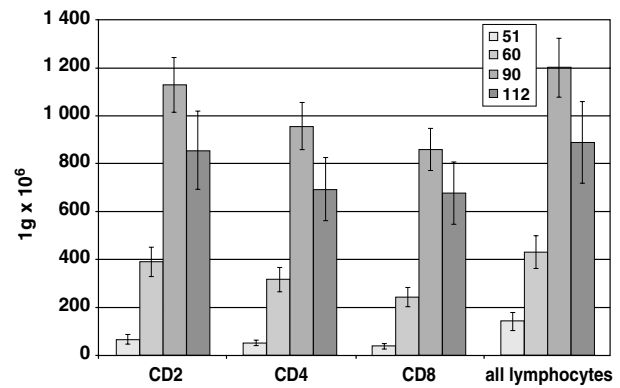

Fig. 6. Count of T-lymphocytes with $\mathrm{CD} 2^{+}, \mathrm{CD} 4^{+}$and $\mathrm{CD} 8^{+}$receptors in thymus during prenatal development (per 1 gram w.w.)

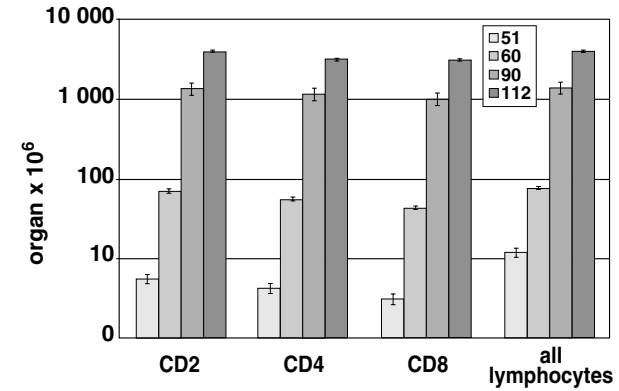

Fig. 7. Count of T-lymphocytes with $\mathrm{CD} 2^{+}, \mathrm{CD} 4^{+}$and $\mathrm{CD} 8^{+}$receptors in thymus during prenatal development (per whole organ) 
Table 1

Proportion of T-lymphocytes with $\mathrm{CD} 2^{+}, \mathrm{CD}^{+}$and $\mathrm{CD} 8^{+}$receptors during prenatal development (\%)

\begin{tabular}{|c|c|c|c|c|c|c|c|c|c|}
\hline \multicolumn{2}{|c|}{ Gestation (days) } & 51 & $\mathrm{n}$ & 60 & $\mathrm{n}$ & 90 & $\mathrm{n}$ & 112 & $\mathrm{n}$ \\
\hline \multirow{4}{*}{ 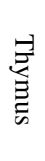 } & $\mathrm{CD}^{+}$ & $45.5 \pm 3.1$ & 7 & $90.0 \pm 7.8$ & 7 & $93.5 \pm 6.5$ & 13 & $96.1 \pm 7.5$ & 7 \\
\hline & $\mathrm{CD}_{4}^{+}$ & $35.1 \pm 2.9$ & 7 & $73.5 \pm 3.1$ & 7 & $79.2 \pm 4.1$ & 13 & $77.7 \pm 5.2$ & 7 \\
\hline & $\mathrm{CD}^{+}$ & $26.0 \pm 2.1$ & 7 & $57.0 \pm 2.7$ & 7 & $71.3 \pm 3.2$ & 13 & $76.2 \pm 4.9$ & 7 \\
\hline & $\mathrm{CD}^{+} / \mathrm{CD}^{+}+$ & $1.35 \pm 0.24$ & 7 & $1.29 \pm 0.12$ & 7 & $1.11 \pm 0.11$ & 13 & $1.02 \pm 0.14$ & 7 \\
\hline \multirow{4}{*}{$\begin{array}{l}\frac{\tilde{c}}{8} \\
\stackrel{8}{g}\end{array}$} & $\mathrm{CD}^{+}{ }^{+}$ & $0.2 \pm 001$ & 7 & $4.4 \pm 0.2$ & 7 & $12.9 \pm 0.8$ & 13 & $45.2 \pm 2.1$ & 7 \\
\hline & $\mathrm{CD}_{4}^{+}$ & $<0.01$ & 7 & $3.0 \pm 0.3$ & 7 & $5.6 \pm 0.3$ & 13 & $33.7 \pm 1.8$ & 7 \\
\hline & $\mathrm{CD}^{+}$ & $<0.01$ & 7 & $0.7 \pm 0.1$ & 7 & $3.8 \pm 0.2$ & 13 & $20.0 \pm 1.2$ & 7 \\
\hline & $\mathrm{CD}^{+} / \mathrm{CD}^{+}$ & ND & 7 & $4.29 \pm 1.21$ & 7 & $1.47 \pm 0.17$ & 13 & $1.65 \pm 0.24$ & 7 \\
\hline \multirow{4}{*}{ 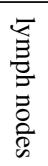 } & $\mathrm{CD}^{+}$ & ND & 7 & ND & 7 & $75.1 \pm 4.3$ & 13 & $84.1 \pm 6.5$ & 7 \\
\hline & $\mathrm{CD}^{+}$ & ND & 7 & ND & 7 & $51.3 \pm 3.1$ & 13 & $57.2 \pm 7.2$ & 7 \\
\hline & $\mathrm{CD}^{+}$ & ND & 7 & ND & 7 & $60.0 \pm 3.7$ & 13 & $67.5 \pm 3.9$ & 7 \\
\hline & $\mathrm{CD}^{+} / \mathrm{CD}^{+}{ }^{+}$ & ND & 7 & ND & 7 & $0.6 \pm 0.11$ & 13 & $0.85 \pm 0.12$ & 7 \\
\hline
\end{tabular}

respectively, and it represents a difference of two and three orders of magnitude, respectively (Fig. 6 and 7). When the curve of subpopulation changes expressed as a function of age was interpolated, it could be suggested that $\mathrm{CD} 4^{+} / \mathrm{CD}^{+}$phenotype was present around FD 40 , i.e. in the period, when the cortex and medulla in thymus were not yet morphologically differentiated (Kruml et al. $1970 \mathrm{ab}$ ). $\mathrm{CD}^{+} / \mathrm{CD}^{+}$ration in this organ decreases from the value 1.35 on FD 51 to 1.02 on FD 112 (Table 1). In the spleen, the secondary lymphatic

Table 2

Proportion of lymphocytes with $\mathrm{CD} 2^{+}, \mathrm{CD}^{+}, \mathrm{CD}^{+}$and $\mathrm{sIgM}^{+}$receptors in circulating blood during prenatal and early postnatal ontogenesis

\begin{tabular}{|c|c|c|c|c|c|c|}
\hline Gestation (days) & FD90 & $\mathrm{n}$ & FD112 & $\mathrm{n}$ & PD28 & $\mathrm{n}$ \\
\hline CD2 & $61.50 \pm 3.50$ & 9 & $68.30 \pm 5.20$ & 7 & $80.40 \pm 2.00$ & 8 \\
\hline CD4 & $11.80 \pm 1.10$ & 9 & $10.90 \pm 1.80$ & 7 & $11.40 \pm 0.90$ & 8 \\
\hline CD8 & $13.60 \pm 3.00$ & 9 & $18.20 \pm 2.80$ & 7 & $54.00 \pm 4.20$ & 8 \\
\hline CD4 / CD8 & $0.87 \pm 0.10$ & 9 & $0.60 \pm 0.05$ & 7 & $0.21 \pm 0.01$ & 8 \\
\hline S IgM & $9.20 \pm 2.50$ & 9 & $11.80 \pm 1.90$ & 7 & $16.50 \pm 2.80$ & 8 \\
\hline CD2 / S IgM & $6.68 \pm 1.45$ & 9 & $5.79 \pm 0.42$ & 7 & $4.87 \pm 0.74$ & 8 \\
\hline
\end{tabular}

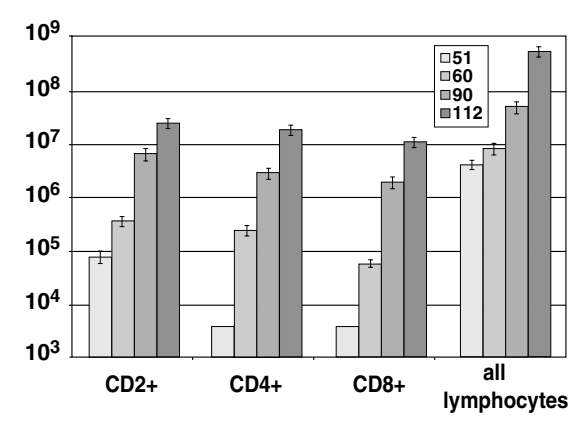

Fig. 8. Count of T-lymphocytes with $\mathrm{CD} 2^{+}, \mathrm{CD} 4^{+}$and $\mathrm{CD} 8^{+}$receptors in spleen during prenatal development (per 1 gram w.w.)

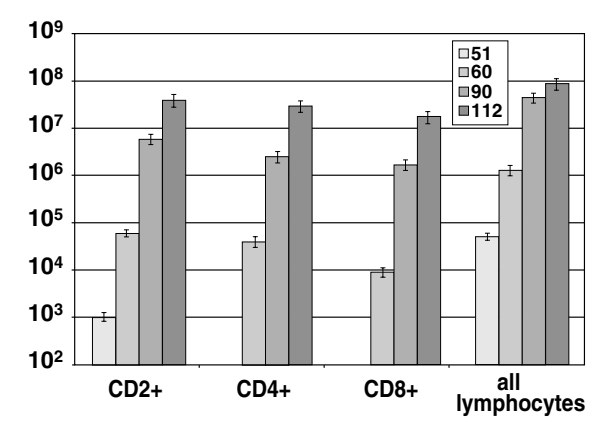

Fig. 9. Count of T-lymphocytes with $\mathrm{CD} 2^{+}, \mathrm{CD}^{+}$and $\mathrm{CD}^{+}$receptors in spleen during prenatal development (per whole organ) 
Table 3

Counts of T-lymphocytes with $\mathrm{CD} 2^{+}, \mathrm{CD} 4^{+}$and $\mathrm{CD} 8^{+}$receptors in mesenteric lymph nodes during prenatal development $\left(10^{6}\right)$

\begin{tabular}{|c|c|c|c|c|}
\hline & \multicolumn{2}{|c|}{ per 1 gram w. w. } & \multicolumn{2}{c|}{ per whole organ } \\
\hline Gestation (days) & 90 & 112 & 90 & 112 \\
\hline $\mathrm{CD}^{+}$ & $4.30 \pm 0.71$ & $4.75 \pm 1.19$ & $50.62 \pm 8.86$ & $126.64 \pm 26.16$ \\
\hline $\mathrm{CD}^{+}$ & $2.94 \pm 0.49$ & $3.23 \pm 0.76$ & $34.58 \pm 6.05$ & $84.77 \pm 17.79$ \\
\hline $\mathrm{CD}^{+}$ & $3.44 \pm 0.54$ & $3.81 \pm 0.90$ & $40.44 \pm 7.08$ & $100.04 \pm 20.99$ \\
\hline all lymphocytes & $5.73 \pm 0.95$ & $5.65 \pm 1.33$ & $67.40 \pm 11.80$ & $148.20 \pm 31.10$ \\
\hline
\end{tabular}

organ, only lymphocytes expressing CD2 ${ }^{+}$marker on FD 51 were confirmed. We assume that it was the T lymphocyte population, although low expression of this phenotype was also confirmed for B cells in pigs (Š ink or a et al. 1998b, 2000). Expression of the surface markers of helper $\left(\mathrm{CD}^{+}\right)$and cytotoxic $\left(\mathrm{CD}^{+}\right)$lymphocytes was not confirmed and was apparently below the level of detection. On FD 60 both of them and also $\mathrm{CD}^{2+}$ of all CD2 $2^{+}$followed by their significant increase up to FD 112 (Table 1). When expressed per 1 gram of wet weight of the spleen and to the whole organ mass this increase represented as a function of age, a difference of two or three orders of magnitude, respectively (Fig. 8 and 9). CD4 ${ }^{+} / \mathrm{CD}^{+}$ ratio decreased in the spleen between FD 60 and FD 112 significantly from 4.29 to 1.65 (Table 1). This was caused mainly by an increased number of cytotoxic CD ${ }^{+}$lymphocytes. Expression of IgM receptors on the surface of the spleen lymphocytes was not carried out in these experiments. Changes in T lymphocyte subpopulations were estimated only in

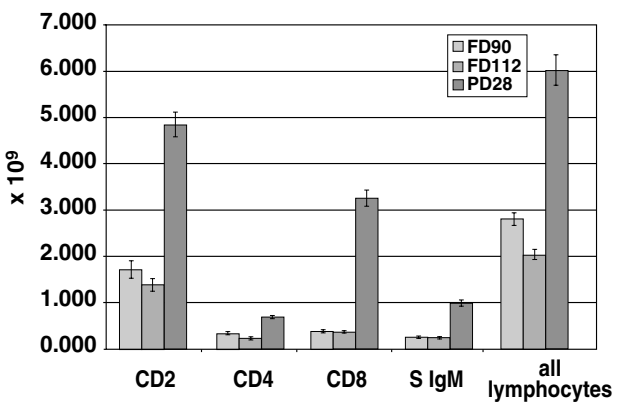

Fig. 10. Proportion of lymphocytes with $\mathrm{CD} 2^{+}, \mathrm{CD}^{+}$, $\mathrm{CD}^{+}$and $\operatorname{sigM}$ receptors per one litre of circulating blood during prenatal and early postnatal ontogenesis mesenterial lymph nodes on FD 90 to FD 112 due to technical reasons (Table 1 and 3 ). Percentage proportion of the individual subpopulations of T lymphocytes was in this secondary lymphatic organ significantly higher than in spleen (Table 1). However, when expressed per 1 gram of wet weight this difference disappeared (Table 3) due to low cellularity of lymph nodes, because of loosely diffused lymphocytes in their histioreticular structure. When related to the whole organ, this trend was more apparent again, since total weight of the mesenterial lymph nodes was significantly higher (Table $3)$. $\mathrm{CD}^{+} / \mathrm{CD}^{+}$ratio decreased in this organ below value 1 , which is given by $\mathrm{CD}^{+}$subpopulation mainly in comparison to other lymphatic organs. In circulating blood we observed expression of the individual subpopulations of T and B lymphocytes with membrane IgM receptor from FD 90 to PD 28. It is evident from Table 2 that postnatally the percent proportion of $\mathrm{CD}^{+}$lymphocytes increased significantly, apparently due to antigenic pressure of microbial flora. This is particularly evident in relation to $1 \mathrm{~L}$ of circulating blood, where this increase reached a value of one order of magnitude higher (Fig. 10). $\mathrm{CD}^{+} / \mathrm{CD}^{+}$index decreased in this case from 0.87 to 0.21 . This characteristic of lymphocyte subpopulations is typical of circulating blood of adult pigs (Boeker et al. 1999; Saalmuller et al. 2001). The numbers of B lymphocytes with IgM receptor in circulating blood gradually increased during the whole observed period so that on PD 28 of postnatal life they approached values very similar to those of adult pigs, both in relative and actual terms (Table 2, Fig. 10). When $\mathrm{CD} 4^{+}$and CD ${ }^{+}$ lymphocytes proportions are taken together and compared to CD2 $2^{+}$cells, it is evident that 
in thymus, lymph nodes and spleen beginning on FD 51, FD 90 and FD 112, respectively, $\mathrm{T}$ lymphocytes expressed both $\mathrm{CD}^{+}$and $\mathrm{CD} 8^{+}$phenotypes. This is confirmed in other papers, where techniques of double and triple marking were used (Šink ora et al. 1998a; Trebichavský et al. 1995; Zuckermann et al. 1999.

\section{Vývoj subpopulací T lymfocytů během prenatálního a postnatálního období života}

U prasečích fétů od 51. do 112. dne gestace a v cirkulující krvi rovněž u postnatálních selat jsme sledovali změny $\mathrm{v}$ zastoupení jednotlivých subpopulací lymfocytů (především $\mathrm{CD} 2^{+}, \mathrm{CD}^{+}{ }^{+} \mathrm{CD} 8^{+}$) v primárních a sekundárních lymfatických orgánech a cirkulující krvi. Pro tato sledování bylo použito techniky průtokové cytofluorimetrie, přičemž vazba specifických monoklonálních protilátek byla vizualizována polyklonálními protilátkami proti myšímu př́ípadně potkanímu Ig značených fluorochromy (PE a FITC). V thymu již 51. den gestace byly prokázány jak $\mathrm{CD}^{+}$, tak $\mathrm{CD}^{+} \mathrm{T}$ lymfocyty. Jejich množství v průběhu dalšího prenatálního vývoje průkazně narůstá a to jak v relativním, tak absolutním vyjádření. Vyneseme-li tento nárůst jako funkci času s následnou interpolací, je možno předpokládat expresi $\mathrm{CD}^{+}, \mathrm{CD}^{+}$fenotypu u thymových lymfocytů kolem 40. dne gestace, tj. v období, kdy v tomto orgánu dosud není patrna jeho morfologická diferenciace na kůru a dřeň.

Ve slezině 51. den gestace jsou přítomny pouze lymfocyty $\mathrm{CD} 2^{+}$. Exprese fenotypu $\mathrm{CD} 4^{+}$ a CD8 ${ }^{+}$byla pozorována až 60 . den prenatálního vývoje. Jejich počet jak v absolutním, tak relativním vyjádření jako funkce času výrazně narůstá a představuje rozdíl tří řádů. Mízní uzliny byly sledovány pouze od 90 . dne gestace, přičemž T lymfocyty v tomto sekundárním lymfatickém orgánu mají vyšší percentuální zastoupení než ve slezině. CD4 ${ }^{+} / \mathrm{CD}^{+}$index ve slezině a thymu $\mathrm{v}$ průběhu vývoje postupně klesá až na hodnotu $1 \mathrm{~s}$ mírnou dominancí CD4 ${ }^{+}$lymfocytární subpopulace. $\mathrm{V}$ mízních uzlinách prasečích fétů můžeme naopak sledovat dominanci $\mathrm{CD}^{+}$subpopulace (index 0.85).

$\mathrm{V}$ postnatálním období jsme prokázali v periferní krvi průkazný nárůst cytotoxických $\mathrm{CD}^{+}$lymfocytů, přičemž index $\mathrm{CD}^{+} / \mathrm{CD}^{+}$klesá z hodnoty 1 až na 0,228 . den gestace. Tato charakteristika lymfoidních subpopulací v cirkulující krvi je typická rovněž pro dospělý věk. Počet B lymfocytů s IgM receptorem v cirkulující krvi naopak od 90. dne prenatálního vývoje až do 28. dne postnatálního života postupně narůstá a to jak v relativním zastoupení (\%), tak i při přepočtu na 1 litr krve.

\section{Acknowledgement}

This work was supported by the Grant Agency of the Czech Republic (304/01/0850), International Scientific Program CEZ: J 16/98: 161700001 FVL VFU Brno and MSM 111100001.

\section{References}

BOEKER, M, PABST, R, ROTHKOTTER, HJ 1999. Quantification of B, T and null lymphocyte subpopulation in the blood and lymphoid organs of the pig. Immunobiology 201: 74-87

JAROŠKOVÁ, L, KOVÁŘŮ, F 1978: Identification of T and B lymphocytes by combinated E-rosette test and surface Ig labelling. J Immunol Methods 22: 253-281

KOVÁŘ̉̊ , F, 1992: Physiological development of immunocompetence in pig fetuses. Habilitation Thesis, VŠV Brno 1-386 (In Czech)

KOVÁŘ Ů, F 1987: Immunological characterization of pig ontogenetic model. DrSc Thesis, MBÚ ČSAV, Praha, Vol I/II, 1-507 (In Czech)

KOVÁŘŮ, F, KOVÁŘŮ, H, FIŠAR, Z 1994: Immunophenotyping markers on T lymphocyte subpopulations in fetal pig development. Histochem J 26: 876-877

KOVÁRƯ, F, KOVÁŘ Ư, H, HALOUZKA, R, ŠPANOVÁ, A, PALÍKOVÁ, M, DRÁBEK, J 1995: Ontogenetic changes in immunophenotyping markers on pig lymphocytes. Proc Royal Micr Soc 30, Pt2: 122-123

KOVÁR̆L̊, F, KOVÁŘŮ, H, TLASKALOVÁ, H, TRÁVNÍČEK, J, TREBICHAVSKY, I, POSPÍŠIL, M, JAROŠKOVÁ, L, ŠTERZL, J 1987: Development of lymphatic tissues and immunocompetence in prenatal and postnatal period in pigs. Proc XXIIIrd World Veterinary Congress, Montreal 
KOVÁŘŮ, F, POSPÍŠIL, M, HOFMAN, J, TREBICHAVSKY, I 1978: The morphological development and some functional features of lymphatic tissue in pig fetuses. Lymphology 11: 252-255

KOVÁŘŮ, F, STOŽICKY, V 1986: Techniques of the experimental surgery in pig fetus. Proc Int Pig Vet Soc Ith Congress, Barcelona, p. 110

KOVÂR̂̉U, F, STOŽICKY, V, KRUML, J, DLABAČ, V, DONÁT, J, NOVOTNÁ, J 1971: Experimental surgery in the fetal period of mammals. Acta Vet Brno, Suppl 3, 40: 1-68

KOVÁŘ Ů, H, KOVÁŘŮ, F, MANDEL, L 1979: Membrane-bound enzymes of lymphoid tissues. I. ATPase and gammaglutamyltranspeptidase activities of intact cells during ontogenetic development of germfree and conventional pigs. Folia Microbiol 24: 51-52

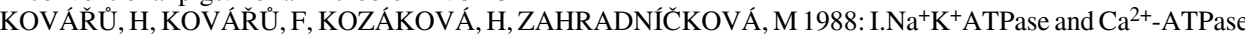
as markers of activated cell stats. Zschr Versuchtierk 31: 173-174

KOVÁŘŨ, H, KOVÁŘŮ, F, TLASKALOVÁ, H, MANDEL, L, TALAFANTOVÁ, M 1988: II. Gammaglutamyltranspeptidase and $\mathrm{Mg}^{2+}$-ATPase as differentiation lymphocyte markers. Zschr Versuchtierk 31: 174

KRUML, J, KOVÁŘŮ, F, LUDVÍK, J, TREBICHAVSKY, I 1970: The development of lymphoid and hemopoietic tissues in pig fetuses. Folia Microbiol 15: 17-22

KRUML, J, KOVÁŘ Ů, F, POSPÍŠIL, M, TREBICHAVSKY, I 1970: The development of lymphatic tissues during ontogeny. Developmental aspects of antibody formation and structure. Academia, Praha, vol. 1, pp. 35-54

PROKEŠOVÁ, L, REJNEK, J, KOVÁŘŮ, F, TRÁVNÍČEK, J, TREBICHAVSKY, I, KOSTKA, J, ŠTERZL, J 1979: Formation and properties of immunoglobulin and antibodies during early ontogeny in pigs. Folia Microbiol 24: 73-74

PROKEŠOVÁ, L, KOVÁŘŮ, F, JAROŠKOVÁ, L, KOSTKA, J, HAVRÁNEK, T, REJNEK, J 1979: Ontogeny of immunoglobulin synthesis of IgM, IgG and IgA in newborn piglets. Dev Comp Immunol 3: 127-138

ŘEHÁKOVÁ, Z, KOVǍŘ Ů, F, ŠPLICHAL, I 1996: Intrauterine immunization. In Immunology Methods Manual - The Comprehensive Sourcebook of Techniques. Edited by I. Lefkovits, Academic Press, vol 3, pp. 1547-1549

SAALMULLER, A, KUEBART, G, HOLLEMWEGUER, E, CHEN, Z, NIELSEN, J, ZUCKERMANN, F, HAVERSON, K 2002: Summary of workshop findings for porcine T-lymphocyte-specific monoclonal antibodies. Vet Immunol Immunop 80: 35-52

ŠINKORA, J, ŘEHÁKOVÁ, Z, ŚINKORA，M, CUKROWSKÁ, B, TLASKALOVÁ-HOGENOVÁ, H, BIANCHI, ATJ, DE GEUS, B 1998a: Expression of CD2 on porcine B lymphocytes. Immunology 95: 443-449

ŠINKORA, M, ŠINKORA, J, ŘEHÁKOVÁ, Z, ŠPLICHAL, I, YANG, H, PARKHOUSE, RME, TREBICHAVSKÝ, I 1998b: Prenatal ontogeny of lymphocyte subpopulations in pigs. Immunology 95: 595-603

ŠINKORA, M, ŠINKORA, J, ŘEHÁKOVÃ, Z, BUTLER, JE 2000: Early ontogeny of thymocytes in pigs: Sequential colonization of the thymus by T cell progenitors. J Immunol 165: 1832-1839

ŠTERZL, J, SILVERSTEIN, AM 1967: Developmental aspects of immunity. Advances in Immunology. Dixon, FJ, Humphrey, JH, Eds, Academic Press, New York/London, 6: 337-459

TREBICHAVSKYY, I, PATRIKOVÁ, I, MANDEL, L, KOVÁŔ̛̛̃, F, ZAHRADNÍČKOVÁ, M 1988: Ontogeny of T lymphocytes in the pig. Folia Microbiol 33: 329-331

TREBICHAVSKÝ, I, ŠINKORA, J, ŘEHÁKOVÁ, Z, ŠPLÍCHAL, I, WHYTE, A, BINNS, R, POSPÍŠIL, R, TUČKOVÁ, L 1995: Distribution of gamma-delta T-cells in the pig fetus. Folia Biol 41: 227-237

ZUCKERMAN, FA 1999: Extrathymic CD4/CD8 double positive T cells. Vet Immunol Immunop 72: 55-66 